\title{
Interaction in computer supported collaborative learning: an analysis of the implementation phase
}

\author{
Núria Hernández-Sellés ${ }^{1 *}$ (D, Pablo-César Muñoz-Carril ${ }^{2}$ (D) and Mercedes González-Sanmamed ${ }^{3}$ (D)
}

\author{
*Correspondence: nuria@ \\ lasallecampus.es \\ ${ }^{1}$ Transmedia project management \\ and design at La Salle Campus \\ Madrid. Facultad de Educación y \\ Ciencias Sociales, C/La Salle, 10, \\ 28023 Madrid, Spain \\ Full list of author information is \\ available at the end of the article
}

\begin{abstract}
There is extensive research on interaction frameworks in distance education and studies in Computer Supported Collaborative Learning (CSCL) have also focused on establishing interaction models. There is still research to be done, though, in order to identify the elements that configure interaction to build up a framework for their integration, aligned with the learning goals. The purpose of this study is to understand the key elements that configure effective interaction in the implementation phase of CSCL and to analyze the different types of interactions that occur during collaborative learning processes. The study was designed under a nonexperimental quantitative methodology and 106 learners answered a questionnaire after participating in 5 different higher education subjects implementing CSCL. A factorial analysis of results prove that students identify three types of interaction to be necessary during the implementation phase of collaboration in order to reach knowledge convergence: cognitive, social and organizational interaction. Therefore, instructors and institutions who wish to promote effective CSCL should bear in mind the learning goals together with the social and organizational aspects interwoven in the design, implementation and assessment phases of collaborative learning.
\end{abstract}

Keywords: Collaborative learning, Higher education, Teaching/learning strategies, Computer-mediated communication, Interactive learning

\section{Introduction}

Computer Supported Collaborative Learning (CSCL) refers to learning situations mediated by technologies where small groups of 3 to 5 students are exposed to interaction in order to solve a complex unstructured problem or are required to design a project (Johnson, Johnson, \& Stanne, 2000). In order to solve the challenge, the group needs to engage in an intense process of cooperation and negotiation which entails, as stated by the Community of Inquiry (CoI) framework, the interrelation of teaching presence, cognitive presence and social presence (Garrison, Anderson, \& Archer, 2000). If collaboration is effectively designed and facilitated through teaching presence, students engage in processes that trigger cognitive presence and knowledge convergence through the construction of shared meaning (Borge, Ong, \& Rosé, 2018; Puntambekar, 2006;

(c) The Author(s). 2020 Open Access This article is licensed under a Creative Commons Attribution 4.0 International License, which permits use, sharing, adaptation, distribution and reproduction in any medium or format, as long as you give appropriate credit to the original author(s) and the source, provide a link to the Creative Commons licence, and indicate if changes were made. The images or other third party material in this article are included in the article's Creative Commons licence, unless indicated otherwise in a credit line to the material. If material is not included in the article's Creative Commons licence and your intended use is not permitted by statutory regulation or exceeds the permitted use, you will need to obtain permission directly from the copyright holder. To view a copy of this licence, visit http://creativecommons.org/licenses/by/4.0/. 
Weinberger, Stegmann, \& Fischer, 2007). The process needs to be grounded on social presence, that is on personal recognition and intra group emotional support (Garrison, Cleveland-Innes, \& Fung, 2010; Näykki, Isohätälä, Järvelä, Pöysä-Tarhonen, \& Häkkinen, 2017; Onrubia \& Engel, 2012).Well-structured collaboration improves individual learning and has a significant influence on students' satisfaction (Johnson et al., 2000; King, 2007; Kwon, Liu, \& Johnson, 2014; Medina \& Suthers, 2008).

The challenge in CSCL situations is to design a fruitful interaction process, since, even though the abilities to cooperate are naturally applied to personal, learning and professional contexts, effective interaction should not be taken for granted when a group of people get together to reach a common goal (Kozlowski \& Ilgen, 2006; Näykki et al., 2017; Pachler, Daly, Mor, \& Mellar, 2010).

\section{Conceptual framework}

Interaction frameworks in distance education identify different types of interaction: learner-instructor interaction, learner-learner interaction, and learner-content interaction (Moore, 1989); interactions among teachers (Garrison \& Shale, 1990); and learner-interface interaction (Hillman, Willis, \& Gunawardena, 1994).

Research in CSCL has also established interaction models that connect its complex dimensions (Hernández-Sellés, Muñoz-Carril, \& González-Sanmamed, 2019; Molinillo, Aguilar-Illescas, Anaya-Sánchez, \& Vallespín-Arán, 2018), identifying a positive and significant influence between:

- teacher-student interaction and students' interaction in their work groups;

- student interaction in work groups and intra-group emotional support;

- student interaction in work groups and collaborative learning;

- online collaborative tools and students' interaction in their work groups.

Learning through collaboration means, therefore, learning through interaction, that explains why interaction is one of the most focal research streams in collaborative learning, and is related to representation, discourse and pattern (Tang, Tsai, \& Lin, 2014). In order to promote effective and positive interactions, it is necessary to establish a careful design phase, where the teacher has the leading role, an implementation phase where students are protagonists and teachers have a facilitating role, and an assessment phase which wraps the process in a coherent evaluation and feedback, scaffolding group work and shared by teachers and students (Garrison et al., 2010; Hernández-Sellés, González-Sanmamed, \& Muñoz-Carril, 2014; Onrubia \& Engel, 2012; Sims, 2003; Stahl, Koschmann, \& Suthers, 2006).

We developed the following table summary (Table 1) by collecting the proposals in the literature related to interaction frameworks in distance education (Hillman et al., 1994; Moore, 1989), taking into account the CSCL proposals from Sims (2003), Stahl et al. (2006), Garrison et al. (2010), Onrubia and Engel (2012), and Hernández-Sellés et al. (2014). We highlight the interaction processes in the three phases of the teachinglearning process: the design, implementation and assessment phases.

Next, we present each phase outlined in the table above, explaining the most significant research results from the perspective of CSCL interaction processes. 
Table 1 Design, Implementation and Assessment phases associated with interaction frameworks. Source: Designed by authors based on the literature review

\begin{tabular}{|c|c|c|c|}
\hline & Design phase & Implementation phase & Assessment phase \\
\hline \multirow{6}{*}{$\begin{array}{l}\text { Instructor- } \\
\text { content } \\
\text { interaction }\end{array}$} & \multirow{2}{*}{$\begin{array}{l}\text { Designing/selecting } \\
\text { problem/project connected } \\
\text { to course competences }\end{array}$} & $\begin{array}{l}\text { Revises student's reactions to } \\
\text { course contents }\end{array}$ & \multirow[t]{6}{*}{$\begin{array}{l}\text { Associates learning outcomes } \\
\text { to course goals/contents }\end{array}$} \\
\hline & & \multirow{5}{*}{$\begin{array}{l}\text { Addresses to new content or } \\
\text { clarifications when necessary }\end{array}$} & \\
\hline & $\begin{array}{l}\text { Selects documentation/ } \\
\text { sources of information }\end{array}$ & & \\
\hline & $\begin{array}{l}\text { Associates expected learning } \\
\text { outcomes to task }\end{array}$ & & \\
\hline & $\begin{array}{l}\text { Defines formative } \\
\text { collaborative assessment }\end{array}$ & & \\
\hline & $\begin{array}{l}\text { Scripts collaboration, defining } \\
\text { expected group exchange } \\
\text { and group formation process }\end{array}$ & & \\
\hline \multirow[t]{2}{*}{$\begin{array}{l}\text { Instructor } \\
\text {-interface } \\
\text { interaction }\end{array}$} & $\begin{array}{l}\text { Selects tools to promote } \\
\text { teacher-student and student- } \\
\text { student exchanges }\end{array}$ & \multirow[t]{2}{*}{$\begin{array}{l}\text { Makes sure tools are promoting } \\
\text { the expected kind of interaction }\end{array}$} & \multirow[t]{2}{*}{$\begin{array}{l}\text { Makes sure tools allow for peer } \\
\text { and process assessment as } \\
\text { well as for final product display }\end{array}$} \\
\hline & $\begin{array}{l}\text { Makes sure tools allow } \\
\text { observation of group } \\
\text { processes }\end{array}$ & & \\
\hline \multirow{6}{*}{$\begin{array}{l}\text { Instructor } \\
\text {-learner } \\
\text { interaction }\end{array}$} & \multirow{6}{*}{$\begin{array}{l}\text { Feeds the design/redesign } \\
\text { process based on student's } \\
\text { course assessment }\end{array}$} & \multirow{2}{*}{$\begin{array}{l}\text { Instructor makes sure } \\
\text { collaboration script, } \\
\text { documentation and interface are } \\
\text { understood }\end{array}$} & Instructor: \\
\hline & & & \multirow[t]{2}{*}{$\begin{array}{l}\text { Promotes peer-assessment anc } \\
\text { process- assessment, individu- } \\
\text { ally and in groups }\end{array}$} \\
\hline & & Observes interaction & \\
\hline & & $\begin{array}{l}\text { Offers support (cognitive/social } \\
\text { levels) }\end{array}$ & $\begin{array}{l}\text { Integrates process and peer } \\
\text { assessment with task results }\end{array}$ \\
\hline & & $\begin{array}{l}\text { Learner expects instructor to be } \\
\text { observing and to intervene when } \\
\text { necessary }\end{array}$ & $\begin{array}{l}\text { Integrates cognitive and social } \\
\text { competences }\end{array}$ \\
\hline & & $\begin{array}{l}\text { Asks for support (cognitive/social } \\
\text { levels) }\end{array}$ & $\begin{array}{l}\text { Learner returns peer and } \\
\text { group assessment; evaluates } \\
\text { course design and course } \\
\text { experience }\end{array}$ \\
\hline \multirow[t]{2}{*}{$\begin{array}{l}\text { Learner- } \\
\text { content } \\
\text { interaction }\end{array}$} & \multirow[t]{2}{*}{$\begin{array}{l}\text { Feeds the redesign process } \\
\text { through course assessment }\end{array}$} & $\begin{array}{l}\text { Analyzes collaboration script, } \\
\text { documentation Links the problem } \\
\text { to course contents and } \\
\text { competences }\end{array}$ & $\begin{array}{l}\text { Associates assessment } \\
\text { description to interaction } \\
\text { expectations and learning } \\
\text { outcomes }\end{array}$ \\
\hline & & $\begin{array}{l}\text { Makes an effort to understand task } \\
\text { goal and expectations }\end{array}$ & $\begin{array}{l}\text { Analyzes what is expected of } \\
\text { students in the assessment } \\
\text { process }\end{array}$ \\
\hline \multirow{2}{*}{$\begin{array}{l}\text { Learner- } \\
\text { interface } \\
\text { Interaction }\end{array}$} & \multirow{2}{*}{$\begin{array}{l}\text { Feeds the redesign process } \\
\text { through course assessment }\end{array}$} & Familiarizes with course structure & \multirow{2}{*}{$\begin{array}{l}\text { Makes sure tools allow for peer } \\
\text { and process assessment as } \\
\text { well as for final product display }\end{array}$} \\
\hline & & $\begin{array}{l}\text { Figures out how tools will sustain } \\
\text { teacher-student and student- } \\
\text { student exchanges }\end{array}$ & \\
\hline \multirow{5}{*}{$\begin{array}{l}\text { Learner- } \\
\text { learner } \\
\text { interaction }\end{array}$} & $\begin{array}{l}\text { Feeds the redesign process } \\
\text { through course assessment }\end{array}$ & Group formation process & $\begin{array}{l}\text { Informal exchange on the } \\
\text { perceived process }\end{array}$ \\
\hline & \multirow{4}{*}{$\begin{array}{l}\text { Feeds the redesign process, } \\
\text { based on instructor's analysis } \\
\text { of learner-learner interaction }\end{array}$} & $\begin{array}{l}\text { Establish a social contact Define } \\
\text { strategies to solve the problem }\end{array}$ & \multirow[t]{4}{*}{ Peer-assessment return } \\
\hline & & $\begin{array}{l}\text { Interact to reach the goal } \\
\text { (organization) }\end{array}$ & \\
\hline & & $\begin{array}{l}\text { Interact to provide an answer } \\
\text { (cognitive) }\end{array}$ & \\
\hline & & Interact as peers (social) & \\
\hline
\end{tabular}




\section{Design phase}

Fruitful interaction needs to be carefully planned and structured considering the pedagogical, curricular and technological elements connected to the learning process that's being designed (Hernández-Sellés et al., 2014; Medina \& Suthers, 2008; Pineda, Hennig, \& Segovia, 2013). Research suggests the selection of problem/project-based learning or at least complex tasks that allow for the incorporation of generic, transversal and course competences associated to CSCL (Bell, 2010; Prichard, Bizo, \& Stratford, 2006; Williams, Morgan, \& Cameron, 2011).

The election of technologies should be aligned with these objectives, promoting a fluent interaction both at the cognitive and the social level, to sustain problem solving through collaboration and effective teacher-student and student-student communication (Lu, Lajoie, \& Wiseman, 2010; Strijbos, Martens, \& Jochems, 2004).

Scripting collaboration implies the design of a model to guide students to an understanding of the philosophy of collaboration: why and how they are going to interact, how this will lead them to different learning outcomes, what kind of exchanges are expected of them and how they will form the group and plan the task resolution (Dillenbourg \& Hong, 2008; Haake \& Pfister, 2010; Onrubia \& Engel, 2012; Sobreira \& Tchounikine, 2012; Strijbos et al., 2004).

\section{Implementation phase}

In collaborative processes each individual re-structures previous knowledge and learns to cooperate with others through socio-cognitive negotiation; therefore interaction is established at these three levels, the social, cognitive and organizational level that directs the flow of group exchange to reach the established goals (Borge et al., 2018; King, 2007; Stahl, 2004).

Research is conclusive on the need for social interaction, to promote emotional intragroup support and to recognize individuals at a personal level (Akyol, Garrison, \& Ozden, 2009; Capdeferro \& Romero, 2012; King, 2007; Kwon et al., 2014; Vuopala, Hyvönen, \& Järvelä, 2016). To strengthen the commitment of the group towards the resolution of the common goal, students need to establish a sense of community which cares for emotions and motivation, leading to a more fluent communication and to feelings of belonging (Garrison et al., 2000; Kreijns, Kirschner, \& Jochems, 2003; Rovai, 2002). Indeed, the lack of social interaction results in poor cognitive exchange and academic failure, associated to the feelings of isolation (Garrison et al., 2010; Garrison \& Cleveland-Innes, 2005; Onrubia \& Engel, 2012). In this sense, teacher-student interaction should focus on motivation and support, as well as on immediate quality feedback (Kuo, Walker, Schroder, \& Belland, 2014; Packham, Brychan, \& Miller, 2006).

Cognitive interaction occurs through the negotiation of a shared meaning or knowledge convergence, where the group makes an effort to integrate every individual contribution into a common construct and group members are exposed to knowledge convergence and divergence (Borge et al., 2018; King, 2007; Stahl, 2004; Stahl, 2006; Weinberger et al., 2007).

Research highlights that even at well-designed processes students often fail to establish a fruitful learning exchange, since group organization is often a challenge. That's why teachers should support students and redirect to a consistent socio-cognitive 
process leading to what is called the socio-metacognitive expertise (Strijbos et al., 2004, King, 2007; Weinberger et al., 2007; Prichard et al., 2006; Borge et al., 2018). It is important to note that at the implementation phase, group organization will highly rely on students. Self-regulation will allow for the building of the group identity and will promote the training on the associated competences as well as the opportunities for free cognitive divergence and convergence.

At this stage, teacher presence needs to be very active and alert, to avoid feelings of isolation associated to online learning with poor teacher-student and studentstudent interaction, as well as to ground the basis for cognitive and social presence (Akyol et al., 2009; Garrison et al., 2010; Kwon et al., 2014; Strijbos et al., 2004; Vuopala et al., 2016).

\section{Assessment phase}

In any learning process, assessment should establish a coherence with learning methods and inform students of the type of achievements expected individually. In CSCL the learning process is articulated through cognitive and social interaction; that's why assessment in CSCL should integrate both the process of interaction and the result of interaction, assessing student's competencies linked to collaboration as well as task results (Balderas, Palomo-Duarte, Dodero, et al., 2018; Evans, 2013; Gikandi, Morrow, \& Davis, 2011; Lee, Chan, \& Van Aalst, 2006; Macdonald, 2003; Pachler et al., 2010).

In order to keep a more coherent framework, if learning has occurred during interaction, assessment should also involve students in peer assessment, integrating the cognitive and social elements in the process (Pachler et al., 2010; Pérez-Mateo \& Guitert, 2012; Strijbos et al., 2004).

Considering the literature review and the importance of the implementation phase, we designed a study to determine the learners' perceptions about the aspects that shape the interactions that occur in the CSCL implementation phase.

\section{Methodology}

\section{Objectives}

We present here the analysis of the interactions that occur in the implementation phase based on a CSCL experience.

The specific objectives of this study are to:

1. evaluate the importance of the aspects that shape the interactions in the CSCL implementation phase;

2. identify the types of interactions that occur in the implementation phase in a CSCL process.

\section{Procedure and participants}

The research context involves five online university subjects from a Spanish University. Two subjects are part of a primary education degree and the other three subjects are part of a pre-primary education degree.

These subjects implemented CSCL projects during three months. Teachers collaborated in the instructional design in order to guarantee consistency. The collaboration 
was structured in the following steps: 1) Task communication through a collaboration script that suggested the drafting of group agreements, suggestions for project planning, role assignment, describing the media suggested for group exchange and a background on collaborative competences, focusing on organizational, social and cognitive skills; 2) Spontaneous group formation; 3) Drafting of group agreements; 4) Instructor revision of group agreements and feedback to groups; 5) Project implementation with instructor supervision and feedback; 6) Intergroup contrasting of results; 7) Online self- and peerassessment of process and results; 8) Instructor group assessment and individual adjusted assessment.

\section{Data collection instrument}

An ex post facto design based on the questionnaire method was used to collect data (McMillan \& Schumacher, 2005), carried out with an ad hoc questionnaire.

In the questionnaire design process, we verified key psychometric conditions such as validity and reliability. To ensure validity, the questionnaire was reviewed by five experts in research methodology, collaborative work and educational technology, who analyzed aspects such as the uniqueness, relevance and importance of each item. A pilot study was also carried out with 25 students whose comments allowed us to optimize the questionnaire. After the completion of both validation processes, the final questionnaire was set up. It included a section related to the analysis of interaction in the implementation phase of CSCL. Table 5 shows the 16 items that were analyzed in the study.

To ensure reliability, we applied Cronbach's alpha. As McMillan and Schumacher (2010) point out, this index is the most widely used to evaluate the internal consistency of the items in a survey. It also allows to identify and delete from the scale those items that contribute little or nothing to the overall internal consistency of the questionnaire. The high result of .921 confirmed the internal consistency of the questionnaire.

The questionnaires were answered anonymously. Participants were informed of the purposes of the study and gave their consent to participate in the research.

The sample included 106 questionnaires, which represents $83.46 \%$ of the students enrolled in the degrees. The sampling technique was non-probabilistic, accidental or convenience (Cohen \& Manion, 1990; McMillan \& Schumacher, 2005). Statistical analyses were carried out with the SPSS 20 program.

\section{Results}

To fulfil the second objective, we carried out an exploratory factor analysis. This allowed us to identify three types of interactions that occur in CSCL environments: cognitive, social and organizational interactions.

In order to check the applicability conditions of the principal component factor analysis, we used Bartlett's sphericity test and the Kaiser-Meyer-Olkin (KMO) sample adequacy measure. The Barlett test contrasts the null hypothesis that the correlation matrix is an identity matrix, in which case there would be no significant correlations between the variables and the factorial model would not be relevant. On the other hand, the KMO test contrast the fact that partial correlations are small. If the KMO statistic, which ranges between the values 0 and 1 , is high (greater than 0.4 ), it is 
appropriate to develop a factor analysis, but if the value is low, it is inappropriate to carry out a factor analysis (Crespín, 2016).

As we can see in Table 2, the results of Bartlett's sphericity test ( $p$-value $=0.000$ ) show that it is possible to apply the factor analysis. In addition, the KMO statistic obtains a score of 0.872 , a value very close to the unit, which indicates that the data adapt well to a factor analysis model.

The factor analysis carried out with varimax rotation (Table 3) identified a total of three components with a total percentage of explained variance of $62.26 \%$. Factor 1 explains $46.37 \%$ of the variance, factor 2 explains $8.30 \%$, and factor 3 explains $7.58 \%$.

Table 4 shows the rotated component matrix. The distribution of the variables in the CSCL interaction processes are organized based on the three identified components.

The first component refers to aspects of cognitive interaction, the second component refers to aspects related to social interaction processes, while the last component refers to aspects of organizational interaction.

Cognitive interactions are those linked to cognition (task resolution in collaboration); social interactions are those at a social level (emotional intra-group support and personal recognition); and organizational interactions are those linked to group selfregulation and organization to work effectively throughout the process (in this phase teachers transfer leadership to students).

To fulfil objective 1, we used descriptive statistics involving frequencies and percentages as well as measures of central tendency (average) and dispersion (standard deviations).

As Table 5 shows, the average scores obtained by the items belonging to the three types of interactions in CSCL environments are, in general, high, since all items obtained percentages in the "high" and "very high" categories. In relation to cognitive interaction, learners consider the most important aspects for carrying out group tasks in virtual environments to be "develop the capacity for criticism and self-criticism" and "the ability to make consensual decisions" (mean of 4.51 in both cases); while the item "make contributions to the team outside the task (knowledge, experience or information)" (mean of 4.20) has the lowest mean compared to the rest.

In terms of social interaction, learners identify that "treating teammates with respect" (mean 4.70) is one of the most important elements to take into account for carrying out collaborative work online. "Sharing experiences related to the task" (mean of 4.40) is the item with the lowest mean score in this factor.

Finally, for organizational interaction, the item that has the highest mean is "help other team members to learn" (average of 4.23), while the item with the lowest mean score is "establish times in which the effectiveness of the team organization is assessed" (mean 3.96).

Regarding the correlations (Table 6), there is a significant positive relationship between cognitive interaction and social interaction $(\mathrm{r}=.709 ; p<.001)$, as well as between

Table $2 \mathrm{KMO}$ measure and Bartlett's sphericity test

\begin{tabular}{lll}
\hline Kaiser-Meyer-Olkin sample adequacy measure & & .872 \\
\hline Bartlett's sphericity test & Chi-square approximate test & 892,054 \\
& df & 120 \\
& Sig. & .000 \\
\hline
\end{tabular}


Table 3 Total variance explained by the principal component analysis

\begin{tabular}{|c|c|c|c|c|c|c|c|c|c|}
\hline \multirow[t]{2}{*}{ Component } & \multicolumn{3}{|c|}{ Eigenvalues } & \multicolumn{3}{|c|}{$\begin{array}{l}\text { Sums of the squared } \\
\text { saturations of the extraction }\end{array}$} & \multicolumn{3}{|c|}{$\begin{array}{l}\text { Sum of the squared saturations } \\
\text { of the rotation }\end{array}$} \\
\hline & Total & $\begin{array}{l}\% \text { of } \\
\text { variance }\end{array}$ & $\begin{array}{l}\% \\
\text { accumulated }\end{array}$ & Total & $\begin{array}{l}\% \text { of } \\
\text { variance }\end{array}$ & $\begin{array}{l}\% \\
\text { accumulated }\end{array}$ & Total & $\begin{array}{l}\% \text { of } \\
\text { variance }\end{array}$ & $\begin{array}{l}\% \\
\text { accumulated }\end{array}$ \\
\hline 1 & 7.419 & 46.371 & 46.371 & 7.419 & 46.371 & 46.371 & 3.984 & 24.900 & 24.900 \\
\hline 2 & 1.329 & 8.308 & 54.680 & 1.329 & 8.308 & 54.680 & 3.520 & 22.002 & 46.902 \\
\hline 3 & 1.213 & 7.584 & 62.264 & 1.213 & 7.584 & 62.264 & 2.458 & 15.361 & 62.264 \\
\hline 4 & .929 & 5.806 & 68.070 & & & & & & \\
\hline 5 & .764 & 4.776 & 72.845 & & & & & & \\
\hline 6 & .727 & 4.542 & 77.388 & & & & & & \\
\hline 7 & .650 & 4.060 & 81.448 & & & & & & \\
\hline 8 & .554 & 3.461 & 84.909 & & & & & & \\
\hline 9 & .521 & 3.253 & 88.162 & & & & & & \\
\hline 10 & .399 & 2.495 & 90.657 & & & & & & \\
\hline 11 & .376 & 2.348 & 93.005 & & & & & & \\
\hline 12 & .305 & 1.903 & 94.909 & & & & & & \\
\hline 13 & .289 & 1.806 & 96.715 & & & & & & \\
\hline 14 & .240 & 1.501 & 98.216 & & & & & & \\
\hline 15 & .152 & .951 & 99.167 & & & & & & \\
\hline 16 & .133 & .833 & 100.000 & & & & & & \\
\hline
\end{tabular}

Table 4 Rotated component matrix and reliability

\begin{tabular}{|c|c|c|c|c|}
\hline & \multicolumn{3}{|c|}{ Component } & \multirow{2}{*}{$\begin{array}{l}\text { Cronbach's } \\
\text { alpha }\end{array}$} \\
\hline & 1 & 2 & 3 & \\
\hline Face uncertainties within the team & .841 & .046 & .219 & .886 \\
\hline Manage criticism and self-criticism constructively & .756 & .210 & .075 & \\
\hline Make consensual decisions & .740 & .280 & .165 & \\
\hline Develop group analysis guidelines & .638 & .409 & .300 & \\
\hline Show initiative & .581 & .304 & .233 & \\
\hline $\begin{array}{l}\text { Make contributions to the team outside the task } \\
\text { (knowledge, experience or information) }\end{array}$ & .534 & .342 & .254 & \\
\hline Encourage participation & .506 & .323 & .343 & \\
\hline Exchange information sources & .482 & .425 & .337 & \\
\hline Value the contributions of other team members & .213 & .835 & .230 & .855 \\
\hline Tolerate points of view that are different from your own & .235 & .808 & .297 & \\
\hline Express personal ideas and opinions freely & .190 & .736 & .171 & \\
\hline Treat teammates with respect & .368 & .677 & -.056 & \\
\hline Share experiences related to the task & .486 & .503 & .130 & \\
\hline $\begin{array}{l}\text { Establish times in which the effectiveness of the } \\
\text { team organization is assessed }\end{array}$ & .252 & .127 & .798 & .753 \\
\hline Leadership by the coordinator to mediate in the organization & .225 & .060 & .776 & \\
\hline Help other team members to learn & .132 & .333 & .713 & \\
\hline
\end{tabular}

Note: 1 = Cognitive component; 2 = Social component; 3 = Organizational component 
Table 5 Descriptive statistics, means and standard deviations of the items that make up the three types of interactions in CSCL environments

\begin{tabular}{|c|c|c|c|c|c|c|c|c|c|c|c|c|c|c|}
\hline & \multicolumn{2}{|c|}{$\begin{array}{l}\text { DK } \\
\text { NA }\end{array}$} & \multicolumn{2}{|c|}{$\begin{array}{l}\text { Very } \\
\text { low }\end{array}$} & \multicolumn{2}{|c|}{ Low } & \multicolumn{2}{|c|}{ Medium } & \multicolumn{2}{|c|}{ High } & \multicolumn{2}{|c|}{$\begin{array}{l}\text { Very } \\
\text { high }\end{array}$} & \multirow[b]{2}{*}{ Mean } & \multirow[b]{2}{*}{ SD } \\
\hline & $n$ & $\%$ & $n$ & $\%$ & $\mathrm{n}$ & $\%$ & $n$ & $\%$ & $n$ & $\%$ & $n$ & $\%$ & & \\
\hline \multicolumn{15}{|l|}{ Cognitive interaction } \\
\hline Face uncertainties within the team & 0 & .00 & 0 & .00 & 0 & .00 & 15 & 14.29 & 42 & 40.00 & 48 & 45.71 & 4.31 & .71 \\
\hline $\begin{array}{l}\text { Manage criticism and self-criticism } \\
\text { constructively }\end{array}$ & 0 & .00 & 0 & .00 & 1 & .95 & 6 & 5.71 & 36 & 34.29 & 62 & 59.05 & 4.51 & .65 \\
\hline Make consensual decisions & 1 & .95 & 0 & .00 & 0 & .00 & 7 & 6.67 & 32 & 30.48 & 65 & 61.90 & 4.51 & .76 \\
\hline Develop group analysis guidelines & 0 & .00 & 0 & .00 & 1 & .95 & 9 & 8.57 & 40 & 38.10 & 55 & 52.38 & 4.42 & .69 \\
\hline Show initiative & 0 & .00 & 0 & .00 & 1 & .95 & 10 & 9.52 & 37 & 35.24 & 57 & 54.29 & 4.43 & .71 \\
\hline $\begin{array}{l}\text { Make contributions to the team } \\
\text { outside the task (knowledge, } \\
\text { experience or information) }\end{array}$ & 1 & .95 & 0 & .00 & 1 & .95 & 15 & 14.29 & 46 & 43.81 & 42 & 40.00 & 4.20 & .84 \\
\hline Encourage participation & 1 & .95 & 0 & .00 & 1 & .95 & 8 & 7.62 & 33 & 31.43 & 62 & 59.05 & 4.46 & .81 \\
\hline Exchange information sources & 0 & .00 & 1 & .95 & 1 & .95 & 6 & 5.71 & 39 & 37.14 & 58 & 55.24 & 4.45 & .73 \\
\hline \multicolumn{15}{|l|}{ Social interaction } \\
\hline $\begin{array}{l}\text { Value the contributions of other } \\
\text { team members }\end{array}$ & 0 & .00 & 1 & .95 & 0 & .00 & 3 & 2.86 & 35 & 33.33 & 66 & 62.86 & 4.57 & .65 \\
\hline $\begin{array}{l}\text { Tolerate points of view that are } \\
\text { different from your own }\end{array}$ & 0 & .00 & 0 & .00 & 2 & 1.90 & 3 & 2.86 & 32 & 30.48 & 68 & 64.76 & 4.58 & .65 \\
\hline $\begin{array}{l}\text { Express personal ideas and opinions } \\
\text { freely. }\end{array}$ & 0 & .00 & 0 & .00 & 1 & .95 & 9 & 8.57 & 28 & 26.67 & 67 & 63.81 & 4.53 & .69 \\
\hline Treat teammates with respect & 1 & .95 & 0 & .00 & 0 & .00 & 3 & 2.86 & 21 & 20.00 & 80 & 76.19 & 4.70 & .68 \\
\hline Share experiences related to the task & 1 & .95 & 0 & .00 & 2 & 1.90 & 7 & 6.67 & 38 & 36.19 & 57 & 54.29 & 4.40 & .83 \\
\hline \multicolumn{15}{|l|}{ Organizational interaction } \\
\hline $\begin{array}{l}\text { Establish times in which the } \\
\text { effectiveness of the team } \\
\text { organization is assessed }\end{array}$ & 0 & .00 & 3 & 2.86 & 3 & 2.86 & 20 & 19.05 & 48 & 45.71 & 31 & 29.52 & 3.96 & .93 \\
\hline $\begin{array}{l}\text { Leadership by the coordinator to } \\
\text { mediate in the organization }\end{array}$ & 0 & .00 & 0 & .00 & 4 & 3.81 & 16 & 15.24 & 41 & 39.05 & 44 & 41.90 & 4.19 & .83 \\
\hline Help other team members to learn & 0 & .00 & 0 & .00 & 5 & 4.76 & 13 & 12.38 & 40 & 38.10 & 47 & 44.76 & 4.23 & .85 \\
\hline
\end{tabular}

social and organizational interaction $(\mathrm{r}=.434 ; p<.001)$, and also between cognitive and organizational interaction $(\mathrm{r}=.572 ; p<.001)$.

\section{Discussion}

The purpose of this study was to understand the key elements that configure effective interaction in the implementation phase of CSCL and to analyze the different types of interactions that occur during collaborative learning processes.

Table 6 Spearman correlation matrix for the three types of interactions identified in CSCL

\begin{tabular}{llll}
\hline & 1 & 2 & 3 \\
\hline 1. Cognitive interaction & - & & \\
2. Social interaction & $.709^{* *}$ & - & - \\
3. Organizational interaction & $.572^{* *}$ & $.434^{* *}$ & 4.12 \\
M & 4.42 & 4.57 & .71 \\
SD & .51 & .50 &
\end{tabular}


The insights of the learners who participated in the collaborative learning experience during the 3 months of the project allowed us to identify, through the factor analysis of the results, three types of interactions in the CSCL implementation phase: cognitive, social and organizational interactions. These results are coherent with previous studies (Borge et al., 2018; Garrison et al., 2010; Näykki et al., 2017; Onrubia \& Engel, 2012; Weinberger et al., 2007); therefore, in order for learning to take place in CSCL it is necessary to establish a collaboration culture that integrates cognitive, social and organizational aspects that favor knowledge convergence. This integrated vision considers learners as human beings who, in their interaction processes, need an order and a coordinated process to achieve the related objectives. This is particularly important based on the evidence that even in well-designed collaborative learning processes students tend to interact at a basic level and fail to build up consistent analysis (Borge et al., 2018; King, 2007; Weinberger et al., 2007).

The learners, in fact, considered the three types of interaction to be of great importance. There was a significant positive relationship between cognitive interaction and social interaction, between social and organizational interaction, and also between cognitive and organizational interaction, which further highlights their relevance in the design of learning processes supported by CSCL. Integrating the three types of interaction favors individual learning and learner satisfaction during group work. In this regard, the literature identifies that not considering organizational or social interaction jeopardizes the success of the learning process (Johnson et al., 2000; King, 2007; Kwon et al., 2014; Medina \& Suthers, 2008; Stahl et al., 2006).

In relation to cognitive interaction, learners considered developing a critical and selfcritical capacity and the ability to make consensual decisions to be the most important variables. This is in line with studies such as Stahl, 2006; Weinberger et al., 2007; King, 2007; Borge et al., 2018, that indicate that knowledge convergence in CSCL is developed through the construction of shared meaning both in convergence and divergence cognitive processes.

On the other hand, respect among students has revealed itself as one of the key elements to scaffold social interaction, although other aspects such as tolerance and support were also rated highly. This is consistent with other studies which found that emotional support and respect have a positive influence on collaborative learning (Blasco-Arcas, Buil, Hernández-Ortega, \& Sese, 2013; Molinillo et al., 2018).

Regarding organizational interaction, the most valued item was "help other team members to learn" (mean 4.23). These results are aligned with previous studies that also indicated that managing group coordination favors and develops a sense of support, in addition to relieving anxiety (Kwon et al., 2014; Reyes, Brackett, Rivers, White, \& Salovey, 2012; Vuopala et al., 2016). Indeed, during the implementation phase, learners themselves are the protagonists of the management process, as has been stated in previous research (Garrison et al., 2010; Hernández-Sellés et al., 2014; Onrubia \& Engel, 2012; Sims, 2003; Stahl et al., 2006). In particular, this study shows that effective organization is associated with peer to peer support linked to learning. Therefore, it is necessary to design interaction contexts promoting cognitive and social contact and stablish an organization culture before interaction occurs. At the interaction phase, teachers should be alert that organization is properly managed within groups. 


\section{Conclusions}

To meet the educational challenges related to the barriers found in online education, virtual campuses as well as other initiatives that promote the use of media in learning processes are adopting methodologies that prioritize interaction among the different educational agents (Bates \& Sangrà, 2011; Stahl et al., 2006).

CSCL is a dominant presence in online learning, since it has the potential to improve individual learning and to increase student motivation and perceived satisfaction. Wellstructured collaboration implies recognizing cognitive, social and organizational interactions during the implementation phase, which is supported by the initial design and reinforced by consistent assessment. Teachers and institutions should align themselves with research findings concerning human learning through interaction. Thus, academic performance could be improved by recognizing students in a socio-emotional dimension and supporting well-structured and managed learning, which serves as a basis for developing curricular and extracurricular competences.

\section{Limitations}

It would be interesting to carry out further research into the relevance of interaction in the design and assessment phases of Computer Supported Collaborative Learning. In addition, more empirical studies are required to obtain data from students of different levels and working on disciplines. In this sense, it would be interesting to replicate the research, that is, the factor structure with the three types of interaction in CSCL environments during the implementation phase, with the collaboration of a larger number of higher education institutions.

Acknowledgments

Not applicable.

Authors' contributions

All authors contributed to the research design and development, discussed the results and contributed to the final manuscript. The authors declare that they have no competing interests.

\section{Funding}

This paper has been written in the context of the research project: "Ecologías de aprendizaje en la era digital: nuevas oportunidades para la formación del profesorado de educación secundaria" (ECO4LEARN-SE) "Learning ecologies in the digital era: new opportunities for teacher training in secondary education". It has been partially financed by the Ministry of Science, Innovation and Universities in Spain, (Ref. RTI2018-095690-B-I00).

Availability of data and materials

The datasets used and/or analyzed during the current study are available from the corresponding author on reasonable request.

\section{Competing interests}

The authors declare that they have no competing interests.

\section{Author details}

${ }^{1}$ Transmedia project management and design at La Salle Campus Madrid. Facultad de Educación y Ciencias Sociales, C/La Salle, 10, 28023 Madrid, Spain. ²Pedagogy and Didactics Department and Teacher Training Faculty at the University of Santiago de Compostela, Facultad de Formación del Profesorado, Avda. Ramón Ferreiro, s/n, 27002 Lugo, Spain. ${ }^{3}$ Pedagogy and Didactics Department of the Faculty of Education Sciences at the University of A Coruña, Facultad de Ciencias de la Educación, Campus de Elviña, s/n, 15071 A Coruña, Spain.

Received: 15 January 2020 Accepted: 6 April 2020

Published online: 01 July 2020

\section{References}

Akyol, Z., Garrison, D. R., \& Ozden, M. Y. (2009). Development of a community of inquiry in online and blended learning contexts. Procedia - Social and Behavioral Sciences, 1(1), 1834-1838. https://doi.org/10.1016/j.sbspro.2009.01.324. 
Balderas, A., Palomo-Duarte, M., Dodero, J. M., et al. (2018). Scalable authentic assessment of collaborative work assignments in wikis. International Journal of Educational Technology in Higher Education, 15, 40 https://doi.org/10.1186/s41239-0180122-1.

Bates, A., \& Sangrà, A. (2011). Managing Technology in Higher Education. San Francisco: Jossey-Bass.

Bell, S. (2010). Project-based learning for the 21st century: Skills for the future. The Clearing House: A Journal of Educational Strategies, Issues and Ideas, 83(2), 39-43 https://doi.org/10.1080/00098650903505415.

Blasco-Arcas, L., Buil, I., Hernández-Ortega, B., \& Sese, F. J. (2013). Using clickers in class. The role of interactivity, active collaborative learning and engagement in learning performance. Computers \& Education, 62, 102-110 https://doi.org/10. 1016/j.compedu.2012.10.019.

Borge, M., Ong, Y. S., \& Rosé, C. P. (2018). Learning to monitor and regulate collective thinking processes. IJCSCL, 13(1), 61-92 https://doi.org/10.1007/s11412-018-9270-5.

Capdeferro, N., \& Romero, M. (2012). Are online learners frustrated with collaborative learning experiences? The International Review of Research in Open and Distance Learning, 13(2), 26-44 https://doi.org/10.19173/irrodl.v13i2.1127.

Cohen, L., \& Manion, L. (1990). Métodos de investigación educativa. Madrid: La Muralla.

Crespín, E. (2016). Análisis multivariante. Aplicaciones con SPSS. San Salvador: UFG Editores.

Dillenbourg, P., \& Hong, F. (2008). The mechanics of CSCL macro scripts. International Journal of Computer-Supported Collaborative Learning, 3(1), 5-23 https://doi.org/10.1007/s11412-007-9033-1.

Evans, C. (2013). Making sense of assessment feedback in higher education. Review of Educational Research, 83(1), 70-120 https://doi.org/10.3102/0034654312474350.

Garrison, D.R., Anderson, T., \& Archer, W. (2000). Critical inquiry in a text-based environment: Computer conferencing in higher education. The Internet and Higher Education, 2(2-3), 87-105. https://doi.org/10.1016/S1096-7516(00)00016-6

Garrison, D. R., \& Cleveland-Innes, M. (2005). Facilitating cognitive presence in online learning: Interaction is not enough. American Journal of Distance Education, 19(3), 133-148 https://doi.org/10.1207/s15389286ajde1903_2.

Garrison, D. R., Cleveland-Innes, M., \& Fung, T. S. (2010). Exploring causal relationships among teaching, cognitive and social presence: Student perceptions of the community of inquiry framework. Internet and Higher Education, 13(1), 31-36 https://doi.org/10.1016/j.iheduc.2009.10.002.

Garrison, D. R., \& Shale, D. (1990). Education at a distance: From issues to practice. Melbourne, FL: Krieger https://doi.org/10. 1080/08923649009526713.

Gikandi, J. W., Morrow, D., \& Davis, N. E. (2011). Online formative assessment in higher education: A review of the literature. Computers \& Education, 57(4), 2333-2351 https://doi.org/10.1016/j.compedu.2011.06.004

Haake, J. M., \& Pfister, H.-R. (2010). Scripting a distance-learning university course: Do students benefit from net-based scripted collaboration? International Journal of Computer-Supported Collaborative Learning, 5(2), 191-210.

Hernández-Sellés, N., González-Sanmamed, M., \& Muñoz-Carril, P. C. (2014). La planificación del aprendizaje colaborativo en entornos virtuales. Comunicar, 42, 25-33 https://doi.org/10.3916/C42-2014-02.

Hernández-Sellés, N., Muñoz-Carril, P. C., \& González-Sanmamed, M. (2019). Computer-supported collaborative learning: An analysis of the relationship between interaction, emotional support and online collaborative tools. Computers \& Education, 138, 1-12 https://doi.org/10.1016/j.compedu.2019.04.012.

Hillman, D. C., Willis, D. J., \& Gunawardena, C. N. (1994). Learner-interface interaction in distance education: An extension of contemporary models and strategies for practitioners. American Journal of Distance Education, 8(2), 30-42 https://doi.org/ 10.1080/08923649409526853.

Johnson, D. W., Johnson, R. T., \& Stanne, M. B. (2000). Cooperative learning methods: A meta-analysis. Minneapolis, MN: University of Minnesota.

King, A. (2007). Scripting collaborative learning processes: A cognitive perspective. In F. Fischer, I. Kollar, H. Mandl, \& J. M. Haake (Eds.), Scripting computer-supported collaborative learning: Cognitive, computational and educational perspectives, (pp. 13-37). New York: Springer https://doi.org/10.1007/978-0-387-36949-5_2.

Kozlowski, S. W. J., \& Ilgen, D. R. (2006). Enhancing the effectiveness of work groups and teams. Psychological Science in the Public Interest, 7(3), 77-124 https://doi.org/10.1111/j.1529-1006.2006.00030.x.

Kreijns, K., Kirschner, P. A., \& Jochems, W. (2003). Identifying the pitfalls for social interaction in computer-supported collaborative learning environments: A review of the research. Computers in Human Behavior 19, 335-353. https://doi. org/10.1016/S0747-5632(02)00057-2

Kuo, Y.-C., Walker, A. E., Schroder, K. E. E., \& Belland, B. R. (2014). Interaction, internet self-efficacy, and self-regulated learning as predictors of student satisfaction in online education course. Internet and Higher Education, 20, 35-50 https://doi.org/ 10.1016/j.iheduc.2013.10.001.

Kwon, K., Liu, Y., \& Johnson, L. (2014). Group regulation and social-emotional interactions observed in computer supported collaborative learning: Comparison between good vs. poor collaborators. Computers \& Education, 78, 185-200 https://doi. org/10.1016/j.compedu.2014.06.004.

Lee, E., Chan, C., \& van Aalst, J. (2006). Students assessing their own collaborative knowledge building. International Journal of Computer-Supported Collaborative Learning, 1(1), 57-87 https://doi.org/10.1007/s11412-006-6844-4.

Lu, J., Lajoie, S.P., \& Wiseman, J. (2010) Scaffolding Problem-Based Learning with CSCL Tools in International Journal of Computer-Supported Collaborative Learning, 5(3), 283-298. https://doi.org/10.1007/s11412-010-9092-6

Macdonald, J. (2003). Assessing online collaborative learning: Process and product. Computers \& Education, 40(4), 377-391. https://doi.org/10.1016/S0360-1315(02)00168-9

McMillan, J., \& Schumacher, S. (2010). Research in education: Evidence-based inquiry. Harlow: Pearson Addison Wesley.

McMillan, N., \& Schumacher, S. (2005). Investigación educativa: una introducción conceptual. Madrid: Pearson Addison Wesley.

Medina, R., \& Suthers, D. (2008). Bringing representational practice from log to light. Proceedings of the 8th international conference on International conference for the learning sciences, 59-66.

Molinillo, S., Aguilar-Illescas, R., Anaya-Sánchez, R., \& Vallespín-Arán, M. (2018). Exploring the impacts of interactions, social presence and emotional engagement on active collaborative learning in a social web-based environment. Computers \& Education, 123, 41-52 https://doi.org/10.1016/j.compedu.2018.04.012.

Moore, M. G. (1989). Editorial: Three types of interaction. American Journal of Distance Education, 3(2), 1-7 https://doi.org/10. 1080/08923649309526818. 
Näykki, P., Isohätälä, J., Järvelä, S., Pöysä-Tarhonen, J., \& Häkkinen, P. (2017). (2017) Facilitating socio-cognitive and socioemotional monitoring in collaborative learning with a regulation macro script - An exploratory study. IJCSCL, 12 (3), $251-279$.

Onrubia, J., \& Engel, A. (2012). The role of teacher assistance on the effects of a macro-script in collaborative writing tasks. International Journal of Computer-Supported Collaborative Learning, 7(1), 161-186 https://doi.org/10.1007/s11412-011-91259.

Pachler, N., Daly, C., Mor, Y., \& Mellar, H. (2010). Formative e-assessment: Practitioner cases. Computers \& Education, 54(3), 715721 https://doi.org/10.1016/j.compedu.2009.09.032

Packham, G., Brychan, P., \& Miller, C. (2006). Student and tutor perspectives of on-line moderation. Education and Training, 48(4), 241-251 https://doi.org/10.1108/00400910610671915.

Pérez-Mateo, M., \& Guitert, M. (2012). Which social elements are visible in virtual groups? Addressing the categorization of social expressions. Computers \& Education, 58, 1.234-1.246 https://doi.org/10.1016/j.compedu.2011.12.014.

Pineda, C.; Hennig, C. \& Segovia, Y. (2013). Modelos pedagógicos, trabajo colaborativo e interacción en programas virtuales de pregrado en Colombia: Un camino por recorrer. In Educación y tecnología en México y América Latina. Perspectivas y retos, Revista de Universidad y Sociedad del Conocimiento (RUSC). 10 (2) 187-202. https://doi.org/10.7238/rusc.v10i2. 1739

Prichard, J. S., Bizo, L., \& Stratford, R. J. (2006). The educational impact of team-skills training: Preparing students to work in groups. The British Psychological Society, 76, 119-140 https://doi.org/10.1348/000709904X24564.

Puntambekar, S. (2006). Analyzing collaborative interactions: Divergence, shared understanding and construction of knowledge. Computers \& Education, 47(3), 332-351 https://doi.org/10.1016/j.compedu.2004.10.012.

Reyes, M. R., Brackett, M. A., Rivers, S. E., White, M., \& Salovey, P. (2012). Classroom emotional climate, student engagement, and academic achievement. Journal of Educational Psychology, 104, 700-712 https://doi.org/10.1037/a0027268.

Rovai, A. P. (2002). Building sense of Community at a Distance. The International Review of Research in Open and Distributed Learning, 3(1). https://doi.org/10.19173/irrodl.v3i1.79

Sims, R. (2003). Promises of interactivity: Aligning learner perceptions and expectations with strategies for flexible and online learning. Distance Education, 24(1), 87-103. https://doi.org/. https://doi.org/10.1080/01587910303050.

Sobreira, P., \& Tchounikine, P. (2012). A model for flexibly editing CSCL scripts. International Journal of Computer-Supported Collaborative Learning, 7(4), 567-592 https://doi.org/10.1007/s11412-012-9157-9.

Stahl, G. (2004). Building collaborative knowing: Elements of a social theory of CSCL. In J.-W. Strijbos, P. Kirschner, \& R. Martens (Eds.), What we know about CSCL: And implementing in higher education, (pp. 53-86). Boston, MA: Kluwer https:// doi.org/10.1007/1-4020-7921-4_3.

Stahl, G. (2006). Group cognition: Computer support for building collaborative knowledge. Cambridge: MIT Press https://doi.org/ 10.7551/mitpress/3372.001.0001.

Stahl, G., Koschmann, T., \& Suthers, D. (2006). Computer-supported collaborative learning: An historical perspective. In R. K Sawyer (Ed.), Cambridge handbook of the learning sciences, (pp. 409-426). Cambridge, UK: Cambridge University Press.

Strijbos, J., Martens, R., \& Jochems, W. (2004). Designing for interaction: Six steps to designing computer-supported groupbased learning. Computers \& Education, 42, 403-424 https://doi.org/10.1016/j.compedu.2003.10.004.

Tang, K.-Y., Tsai, C.-C., \& Lin, T.-C. (2014). Contemporary intellectual structure of CSCL research (2006-2013): A co-citation network analysis with an education focus. International Journal of Computer-Supported Collaborative Learning, 9(3), 335363 https://doi.org/10.1007/s11412-014-9196-5.

Vuopala, E., Hyvönen, P., \& Järvelä, S. (2016). Interaction forms in successful collaborative learning in virtual learning environments. Active Learning in Higher Education, 17(1), 25-38 https://doi.org/10.1177/1469787415616730.

Weinberger, A., Stegmann, K., \& Fischer, F. (2007). Knowledge convergence in collaborative learning: Concepts and assessment. Learning and Instruction, 17(4), 416-426 https://doi.org/10.1016/j.learninstruc.2007.03.007.

Williams, K., Morgan, K., \& Cameron, B. (2011). How do students define their roles and responsibilities in online learning group projects? Distance Education, 32(1), 49-62 https://doi.org/10.1080/01587919.2011.565498.

\section{Publisher's Note}

Springer Nature remains neutral with regard to jurisdictional claims in published maps and institutional affiliations.

\section{Submit your manuscript to a SpringerOpen ${ }^{\circ}$ journal and benefit from:}

- Convenient online submission

- Rigorous peer review

- Open access: articles freely available online

High visibility within the field

Retaining the copyright to your article

Submit your next manuscript at $\boldsymbol{s p r i n g e r o p e n . c o m ~}$ 